\title{
Improving Thermal and Electrical Efficiency in Photovoltaic Thermal Systems for Sustainable Cooling System Integration
}

\author{
Mohammad Alobaid"1, Ben Hughes', Dominic O'Connor', John Calautit', \\ Andrew Heyes ${ }^{5}$ \\ ${ }^{1}$ Energy 2050 Group, Department of Mechanical Engineering, University of Sheffield, Western Bank, \\ Sheffield S1 3JD, United Kingdom \\ Department of Mechanical Engineering, Majmaah University, Majmaah, Kingdom of Saudi Arabia \\ e-mail: m.alobaid@mu.edu.sa \\ ${ }^{2}$ Energy 2050 Group, Department of Mechanical Engineering, University of Sheffield, Western Bank, \\ Sheffield S1 3JD, United Kingdom \\ e-mail: ben.hughes@ sheffield.ac.uk \\ ${ }^{3}$ Energy 2050 Group, Department of Mechanical Engineering, University of Sheffield, Western Bank, \\ Sheffield S1 3JD, United Kingdom \\ e-mail: d.oconnor@sheffield.ac.uk \\ ${ }^{4}$ School of Built Environment, University of Nottingham, University Park, Nottingham NG7 2RD, \\ United Kingdom \\ e-mail: John.Calautit1@nottingham.ac.uk \\ ${ }^{5}$ Department of Mechanical Engineering, University of Strathclyde, 16 Richmond Street, \\ Glasgow G11XQ, United Kingdom \\ e-mail: andrew.heyes@strath.ac.uk
}

Cite as: Alobaid, M., Hughes, B., O'Connor, D., Calautit, J., Heyes, A., Improving Thermal and Electrical Efficiency in Photovoltaic Thermal Systems for Sustainable Cooling System Integration, J. sustain. dev. energy water environ. syst., 6(2), pp 305-322, 2018, DOI: https://doi.org/10.13044/j.sdewes.d5.0187

\begin{abstract}
Research into photovoltaic thermal systems is important in solar technologies as photovoltaic thermal systems are designed to produce both electrical and thermal energy, this can lead to improved performance of the overall system. The performance of photovoltaic thermal systems is based on several factors that include photovoltaic thermal materials, design, ambient temperature, inlet and outlet fluid temperature and photovoltaic cell temperature. The aim of this study is to investigate the effect of photovoltaic thermal outlet water temperatures and solar cell temperature on both electrical and thermal efficiency for different range of inlet water temperature. To achieve this, a mathematical model of a photovoltaic thermal system was developed to calculate the anticipated system performance. The factors that affect the efficiency of photovoltaic thermal collectors were discussed and the outlet fluid temperature from the photovoltaic thermal is investigated in order to reach the highest overall efficiency for the solar cooling system. An average thermal and electrical efficiency of $65 \%$ and $13.7 \%$, respectively, was achieved and the photovoltaic thermal mathematical model was validated with experimental data from literature.
\end{abstract}

\section{KEYWORDS}

Solar cooling, Solar collectors, Thermal efficiency, Electrical efficiency, Outlet temperature, Photovoltaic thermal systems, Photovoltaic.

\footnotetext{
${ }^{*}$ Corresponding author
} 


\section{INTRODUCTION}

The demand for energy is increasing around the world due to population growth and industrialisation. Fossil fuels such as oil and natural gas are considered as primary sources of energy. In 2035 more than $80 \%$ of the energy consumption of the United States will be produced by fossil fuels [1]. Producing energy by traditional methods leads to more gas emissions and accelerated global warming. Alternative renewable sources of energy such as solar energy, wind energy and geothermal energy are required [2].

In response to the need for alternative energy sources, solar cooling technologies have become an important factor especially in hot countries due to the huge amount of solar radiation and the need for cooling. Solar cooling systems are environmentally friendly compared to conventional cooling systems and an important technology to reduce gas emissions [3]. Pazheri et al. [4] estimated that a $20 \mathrm{MW}$ solar plant, which would need an area of $1.25 \mathrm{~km}^{2}$, can generate 200 to $300 \mathrm{GWh}$ /year and could save 500,000 barrels of oil per year.

The potential for solar energy and the opportunity to utilize it for cooling purposes depend on the location in the world. Theoretically, $0.6 \%$ of the area of Europe would need to be covered by solar Photovoltaic (PV) panels to satisfy total Europe's electricity consumption [5]. Europe, North America, most of Latin American and western Asia have $100-200 \mathrm{~W} / \mathrm{m}^{2}$ average annual rate of solar radiation while in the Middle East, the value reaches up to $250 \mathrm{~W} / \mathrm{m}^{2}$ [4]. In Europe, the residential sector accounts for about $40 \%$ of energy consumption and heating purposes represents about $68 \%$ of this sector $[6,7]$. In contrast, cooling systems have been the main energy consumer in the residential sectors in hot climatic conditions. In Saudi Arabia, $72 \%$ of residential electricity is consumed by cooling equipment [8].

In the last few years, there has been a growing interest to reduce the initial cost and improve the efficiencies of solar collectors and this leads to reduce overall investment of the solar cooling system. Photovoltaic thermal collectors have been used for several solar cooling projects in order to produce both electricity and thermal energy and this also can improve electrical efficiency by $23.8 \%$ more than the conventional PV panel [9, 10]. Figure 1 shows schematic diagram of solar heating and cooling absorption system which consist of absorption chiller, storage tank, cooling space and controllers.

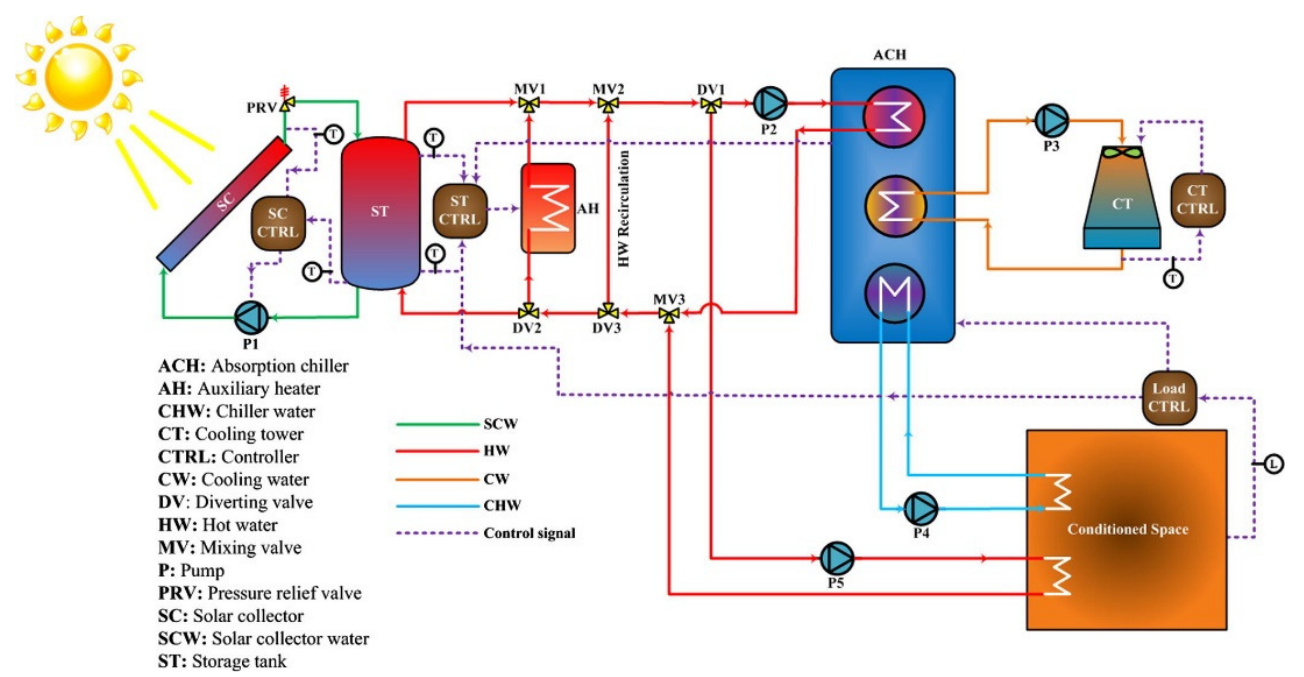

Figure 1. Schematic diagram of solar heating and cooling absorption system [10]

There has been large-scale research that studied Photovoltaic Thermal (PVT) and solar cooling systems separately. However, using PVT to power cooling systems has been rarely examined in literature. For Concentrated Photovoltaic Thermal (CPVT) and 
PVT, the average area to produce cooling in the studied literature for solar absorption chillers was $2.72 \mathrm{~m}^{2} / \mathrm{kW}_{\mathrm{c}}$ and $3.1 \mathrm{~m}^{2} / \mathrm{kW}_{\mathrm{c}}$, respectively [11].

The aim of this study is to investigate the effect of PVT outlet water and solar cell temperature on both electrical and thermal efficiency for different range of inlet water temperature in order to reach the highest overall efficiency for the solar cooling system. The study describes the design and analysis of a PVT system in Saudi Arabia climatic condition. The performance of the system is based on several factors that includes PVT materials, design, ambient temperature, inlet and outlet fluid temperature and PV cell temperature. A mathematical model was developed for a PVT system and the results validated with experimental data from [12].

\section{LITERATURE REVIEW}

Mittelman et al. [13] studied the performance and the economic viability of the use of CPVT collectors for cooling and power generation. The mass and energy balance were applied for each component in the chiller for varying generation temperature from $65^{\circ} \mathrm{C}$ to $120{ }^{\circ} \mathrm{C}$. The finding in the study indicated that electrical efficiency has significant effect of coolant outlet temperature and decreased from $23 \%$ to $20 \%$ with the increase in coolant outlet temperature from $50{ }^{\circ} \mathrm{C}$ to $150{ }^{\circ} \mathrm{C}$ while the thermal efficiency was about $60 \%$ in the same range of the coolant temperature. The authors also reported that the PV cell temperature was $10-30{ }^{\circ} \mathrm{C}$ higher than the outlet coolant temperature. In this system, the thermal energy was considered to be used directly to the absorption chiller without using storage tank which is expected to increase the overall efficiency of the system and decrease the backup heater capacity.

Vokas et al. [14] investigated the use of hybrid PVT collectors instead of Flat Plate Collector (FPC) along with absorption chiller in order to meet the cooling and heating domestic load throughout the year. The performance of the collectors was analysed for different geographical region using the approximation method F-chart. The study highlighted that electrical efficiency of the PVT has improved due to the reduction of its operation temperature and the performance was highly affected by the climate conditions. The study also revealed that FPC can cover $54.26 \%$ of the heating load and $31.87 \%$ of the cooling load while these percentages decreased by $11.9 \%$ and 21.4 in the case of PVT for heating and cooling respectively. Electrical performance for PVT and parameters for FPC weren't reported, the results weren't validated and further justification is needed to explain the decrease in thermal efficiency of PVT.

Calise et al. [15] investigated the performance of solar cooling and heating system based on energy saving and economic analysis by considering a specified case study of a university building in Italy. The PVT collectors of $1,000 \mathrm{~m}^{2}$ were simulated in TRNSYS to produce both electrical and heat energy to supply a $325 \mathrm{~kW}_{\mathrm{c}}$ single lithium bromide absorption chiller that operates at $80{ }^{\circ} \mathrm{C}$, the other components were storage tank, auxiliary heater and cooling tower. The findings of this study indicated that PVT performance is significantly affected by ambient and operation temperature. The authors also found that the PVT system can produce $18 \%$ electrical efficiency at an outlet fluid temperature in the range of $60{ }^{\circ} \mathrm{C}$ to $80{ }^{\circ} \mathrm{C}$. They also reported that the type of the cover of PVT systems is an important factor that affects the PVT performance and further research is required. They highlighted that the tube and sheet c-Si PVT systems show a good ratio of energy production for cooling and heating, but in the study, there was surplus electricity which was sold to the grid or supplied to the building for other purposes.

Calise et al. [16] investigated a dynamic simulation system for cooling, heating and other building demand for electricity in order to find the optimal capacity of a solar collectors field. The study considered a case study in Italy that included $325 \mathrm{~kW}$ double stage absorption chiller $\left(\mathrm{LiBr}-\mathrm{H}_{2} \mathrm{O}\right)$ and CPVT collector area of $996 \mathrm{~m}^{2}$ and TRNSYS has been used to simulate the project throughout the year. The findings in this work 
highlighted that the average thermal and electrical efficiency throughout the year were $32 \%$ and $13.3 \%$ respectively. The primary energy saving and simple payback period were 84.4\% and 15.2 year respectively. Furthermore, the study highlighted the need for a public fund for the CPVT cooling systems in order to become a competitor compared to conventional systems. They reported that no prototype for this system had been tested. Further research is needed to define the optimal value of the capacity and area for solar collectors.

Alobaid et al. [11] published a review paper that focused and discussed the combination of PVT collectors with absorption chiller. The authors highlighted that most of studies in PVT carried out mostly in low temperature climate and focused on heating application where the inlet temperature of PVT is close to the ambient temperature and the outlet fluid temperature less than $60{ }^{\circ} \mathrm{C}$. Thermal collectors efficiencies were in the range of 0.06-0.64 and sufficient efficiency for the PVT could be achieved in the range of outlet temperature of $60-80{ }^{\circ} \mathrm{C}$. Generally, the performance of the solar collector was highly affected by ambient temperature, inlet temperature, solar radiation and the configuration of the collectors.

PVT water collectors were classified based on heat exchanging method and water flow pattern into sheet and tube, channel free flow and two absorber collector [17]. The maximum thermal and electrical efficiency of sheet and tube PVT for the study were $70 \%$ and $15 \%$ respectively. The main absorber materials that are usually used as a main component in PVT and the main features that affect efficiency which included thickness, density, thermal conductivity and heat capacity are reported in Table 1.

Table 1. Main features of absorber materials [17]

\begin{tabular}{ccccc}
\hline Absorber material & $\begin{array}{c}\text { Thickness } \\
{[\mathrm{mm}]}\end{array}$ & $\begin{array}{c}\text { Density } \\
{\left[\mathrm{kg} / \mathrm{m}^{3}\right]}\end{array}$ & $\begin{array}{c}\text { Thermal conductivity } \\
{[\mathrm{W} / \mathrm{mK}]}\end{array}$ & $\begin{array}{c}\text { Heat capacity } \\
{[\mathrm{J} / \mathrm{kgK}]}\end{array}$ \\
\hline Copper & $\sim 0.3$ & 8,920 & 380 & 350 \\
Aluminum & $\sim 1$ & 2,700 & 160 & 900 \\
Steel & $\sim 2$ & 7,860 & 50 & 450 \\
Polymer & $\sim 2-3$ & $900-1,500$ & $0.2-0.8$ & $1,200-1,800$ \\
\hline
\end{tabular}

Cristofari et al. [18] developed a PVT system using a finite difference method to study thermal and electrical efficiency. The authors reported that yearly average thermal and electrical efficiency was $55 \%$ and $12.7 \%$ respectively. The authors also reported that the use of copolymer in the PVT could reduce the cost and weight of the module.

Dubeyand Tay [19] developed a $10 \mathrm{~kW}_{\mathrm{p}}$ PVT array made of 52 panels. Theoretically, the performance of the system was calculated by solving energy equation with several assumptions such as: the heat capacity for the materials in the system was neglected compared to the heat capacity of the water and, one dimensional heat transfer was assumed, steady state, and no temperature stratification in the storage tank. The authors calculated the optimum flowrate for the PVT system to be $0.039 \mathrm{~kg} / \mathrm{sm}^{2}$ and the average thermal and electric efficiency were $34 \%$ and $12 \%$ respectively.

Yazdanifard et al. [20] developed a mathematical model to investigate the effect of solar radiation, geometry and Reynolds number on the performance of flat plat PVT system. In this study, glazed PVT system provides higher efficiency compared to unglazed system. The authors reported that the length of the collector affected the total PVT efficiency.

The current developments in the field of PVT collectors for cooling purposes have been reported in this section. Efficiency for the PVT was achieved in the range of outlet temperature of $60{ }^{\circ} \mathrm{C}$ to $80{ }^{\circ} \mathrm{C}$. Despite the fact that there has been an improvement of the electrical efficiency due to reduced the PV temperature by the coolant in the PVT system, there is an opportunity to utilize the outlet water from PVT to further enhance the solar 
cooling system. Electrical efficiency and thermal efficiency for the PVT are largely affected by ambient temperature and global solar radiation. The performance and outlet fluid temperature for PVT in different climate conditions and inlet temperature, requires further information.

\section{RESEARCH METHOD}

The parameters of the PVT and the weather data were mainly taken from the experiment conducted by Bahaidara et al. [21] in Saudi weather (Dhahran). There were missing information in the experiment about some characteristics of the PVT so some parameters which included $U_{\mathrm{L}}, U_{\mathrm{T}}$ and $U_{\mathrm{tT}}$ were assumed based on Duebey [19] theoretical model. The inlet temperature in the experiment was taken from insulated tank and not given in the article. In this study the inlet temperature was assumed to be less than ambient temperature and the fluid temperature $T_{\mathrm{f}}$ was assumed to be $\left(T_{\mathrm{i}}+T_{\mathrm{o}}\right) / 2$. The PV cell temperature was predicted during the day by the mathematical model and validated with the experiment results.

\section{Photovoltaic Thermal energy balance}

In order to solve energy equations and calculate the performance of the PVT system, the following assumptions were applied [19, 22]:

- Heat capacity for the materials in the system was neglected compared to the heat capacity of the water;

- Steady state, one dimensional heat transfer method was applied;

- Properties were independent of temperature.

Energy balance equation was applied on the PVT collectors which consist of PV cell, plate, channel and fluid. Applying energy balance on any layer of the PVT leads to the eq. (1) which represent the change in internal energy for the PVT collector $\left(M_{\mathrm{i}} C_{\mathrm{i}} \frac{d T_{\mathrm{i}}}{d t}\right)$ as a function of energy gain $\left(\sum Q_{\mathrm{i}}\right)$ and the energy out of the system by losses $\left(\sum Q_{\mathrm{o}}\right)$ [23]:

$$
M_{\mathrm{i}} C_{\mathrm{i}} \frac{d T_{\mathrm{i}}}{d t}=\sum Q_{\mathrm{i}}-\sum Q_{\mathrm{o}}
$$

Applying eq. (1) on the PV layer leads to eq. (2):

$$
M_{\mathrm{PV}} C_{\mathrm{PV}} \frac{d T_{\mathrm{PV}}}{d t}=\sum A_{\mathrm{PV}} G \tau_{\mathrm{PV}} \alpha_{\mathrm{PV}}-\sum Q_{\mathrm{o}}
$$

\section{Mathematical thermal performance}

Thermal efficiency is the ratio of the collected energy to the energy that reaches the solar collector area. Thermal efficiency is calculated by the following expression $[19,12,24]$ :

$$
\eta_{\mathrm{th}}=C_{\mathrm{p}} \dot{m} \frac{T_{\mathrm{o}}-T_{\mathrm{i}}}{G A_{\mathrm{c}}}
$$

The useful energy is calculated by the following expression $[12,19,22,25]$ :

$$
Q_{\mathrm{u}}=A_{\mathrm{c}}\left[\alpha \tau G-U_{\mathrm{L}}\left(T_{\mathrm{pm}}-T_{\mathrm{a}}\right)\right]
$$

In order to calculate useful energy from eq. (4), the plate temperature needs to be measured or calculated. For this reason, heat removal factor $\left(F_{\mathrm{R}}\right)$ and inlet fluid temperature $\left(T_{\mathrm{i}}\right)$ were added to eq. (4) to be written as: 


$$
Q_{\mathrm{u}}=F_{\mathrm{R}} A_{\mathrm{c}}\left[\alpha \tau G-U_{\mathrm{L}}\left(T_{\mathrm{i}}-T_{\mathrm{a}}\right)\right]
$$

or:

$$
Q_{\mathrm{u}}=F_{\mathrm{R}} A_{\mathrm{c}}\left[h_{\mathrm{p} 1} h_{\mathrm{p} 2} \alpha \tau G-U_{\mathrm{L}}\left(T_{\mathrm{i}}-T_{\mathrm{a}}\right)\right]
$$

Collector heat removal factor $\left(F_{\mathrm{R}}\right)$ is the ratio of actual useful energy gain of a collector to the useful gain if the collector surface is assumed at the inlet fluid temperature [22]. Mathematically, $F_{\mathrm{R}}$ is given by the following expression:

$$
F_{\mathrm{R}}=\frac{m^{\prime} C_{\mathrm{p}}\left(T_{\mathrm{o}}-T_{\mathrm{i}}\right)}{A_{\mathrm{c}}\left[S-U_{\mathrm{L}}\left(T_{\mathrm{i}}-T_{\mathrm{a}}\right)\right]}
$$

$S$ is the solar radiation absorbed by the collector and can be written as:

$$
S=\alpha \tau G
$$

Collector efficiency factor $\left(F^{\prime}\right)$ is the ratio of the actual useful energy gain (if the absorber surface has the same temperature of local water) to the useful gain [22]. $F^{\prime}$ is a function of many parameters including inlet fluid temperature, outlet fluid temperature, ambient temperature and written as:

$$
\left[\frac{\left(T_{\mathrm{o}}-T_{\mathrm{a}}-\frac{S}{U_{\mathrm{L}}}\right)}{\left(T_{\mathrm{i}}-T_{\mathrm{a}}-\frac{S}{U_{\mathrm{L}}}\right)}\right]=\exp \frac{-A_{\mathrm{c}} U_{\mathrm{L}} F^{\prime}}{m^{\prime} C_{\mathrm{p}}}
$$

Then the heat removal factor was expressed $[12,19,22]$ as:

$$
F_{\mathrm{R}}=\frac{m^{\prime} C_{\mathrm{p}}}{A_{\mathrm{c}} U_{\mathrm{L}}}\left[1-\exp \left(-\frac{A_{\mathrm{c}} U_{\mathrm{L}} F^{\prime}}{m^{\prime} C_{\mathrm{p}}}\right)\right]
$$

By calculating useful energy, PVT outlet fluid temperature $\left(T_{\mathrm{o}}\right)$ is written as:

$$
T_{\mathrm{o}}=T_{\mathrm{i}}+\frac{Q_{\mathrm{u}}}{m^{\prime} C_{\mathrm{p}}}
$$

\section{Mathematical electrical performance}

The method that is widely used in the literature to calculate PVT electrical performance is to calculate the maximum current power and voltage especially for experimental projects $[12,21]$. The method that is proposed here is utilized to calculate electrical performance based on the average temperature of the PV layer. In order to calculate the PV temperature back surface temperature was worked out based on the PVT configuration and the model shown in Figure 2.

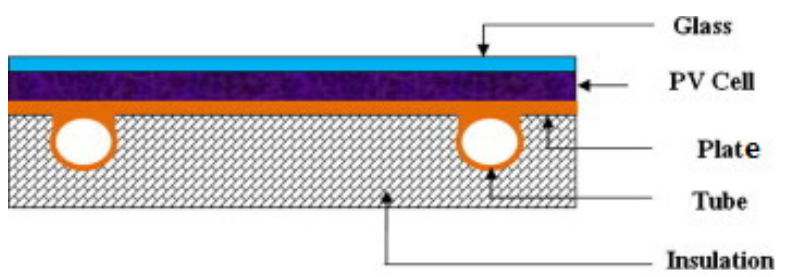

Figure 2. Sheet and tube hybrid PVT collector [23] 
Table 2 shows the the values of design parameters used in the mathematical model the PVT panel.

Table 2. The values of design parameters used in the mathematical model

\begin{tabular}{cc|cc}
\hline Parameter & Value & Parameter & Value \\
\hline$A_{\mathrm{c}}\left[\mathrm{m}^{2}\right]$ & 1.24 & $h_{\mathrm{T}}\left[\mathrm{W} / \mathrm{m}^{2} \mathrm{k}\right]$ & 45 \\
$C_{\mathrm{p}}[\mathrm{J} / \mathrm{kgk}]$ & 4,190 & $h_{\mathrm{p} 1}$ & 0.954 \\
$L_{\mathrm{g}}[\mathrm{m}]$ & 0.003 & $h_{\mathrm{p} 2}$ & 0.854 \\
$L_{\mathrm{si}}[\mathrm{m}]$ & 0.0003 & $\alpha_{\mathrm{sc}}$ & 0.9 \\
$\beta_{\mathrm{c}}$ & 0.83 & $\beta_{\mathrm{o}}$ & 0.0045 \\
$F^{\prime}$ & 0.956 & $\eta_{\mathrm{o}}$ & 0.15 \\
$F_{\mathrm{R}}$ & 0.948 & $\tau_{\mathrm{g}}$ & 0.96 \\
$m^{\prime}[\mathrm{kg} / \mathrm{s}]$ & 0.1 & $U_{\mathrm{T}}\left[\mathrm{W} / \mathrm{m}^{2} \mathrm{k}\right]$ & 150 \\
$U_{\mathrm{b}}\left[\mathrm{W} / \mathrm{m}^{2} \mathrm{k}\right]$ & 0.84 & $U_{\mathrm{tT}}\left[\mathrm{W} / \mathrm{m}^{2} \mathrm{k}\right]$ & 6.81 \\
$U_{\mathrm{L}}\left[\mathrm{W} / \mathrm{m}^{2} \mathrm{k}\right]$ & 5.81 & Number of cells $(\mathrm{mono} \mathrm{crystalline})$ & 72 \\
\hline
\end{tabular}

PV cell temperature $\left(T_{\text {cell }}\right)[12]$ :

$$
T_{\text {cell }}=\frac{\alpha \tau G+U_{\mathrm{T}} T_{\mathrm{a}}+U_{\mathrm{T}} T_{\mathrm{bs}}}{U_{\mathrm{t}}+U_{\mathrm{T}}}
$$

PV back surface temperature [12]:

$$
T_{\mathrm{bs}}=\frac{h_{\mathrm{p} 1} \alpha \tau G+U_{\mathrm{T}} T_{\mathrm{a}}+h_{\mathrm{f}} T_{\mathrm{f}}}{U_{\mathrm{tT}}+h_{\mathrm{f}}}
$$

Electrical efficiency and output electrical power then worked out by the following expressions:

Output electric power $\left(E_{\mathrm{PV}}\right)$ :

$$
E_{\mathrm{PV}}=\eta_{\mathrm{SC}} \times A_{\mathrm{m}} \times G
$$

PV's cell electric efficiency $\left(\eta_{\mathrm{SC}}\right)$ :

$$
\eta_{\mathrm{SC}}=\eta_{\mathrm{o}}\left[1-\beta\left(T_{\mathrm{sc}}-25^{\circ} \mathrm{C}\right)\right]
$$

\section{RESULTS AND DISCUSSION}

In this section, the mathematical model is used to calculate the performance of the PVT. Model validation is discussed and investigation for different inlet temperature is illustrated.

Weather data in Figure 3 were used in the mathematical model to calculate different temperatures that affect PVT performance. This included back surface temperature which is a function of instant solar radiation, ambient temperature and fluid temperature. PV cell temperature was also included which is a function of instant solar radiation, ambient temperature and back surface temperature.

Figure 4 shows ambient temperature, inlet fluid temperature, outlet fluid temperature, PV cell temperature and back surface temperature during Bahaidara experiment day.

The results show that the PVT performance were influenced by several factors that included instant solar radiation, ambient temperature, inlet fluid temperature, PV cell temperature and back surface temperature. As in last figure in next chapter, thermal efficiency was in the range of $72 \%$ at $9 \mathrm{AM}$ to $83 \%$ at $4 \mathrm{PM}$ and the minimum efficiency was $70.6 \%$ between 11 and 12 PM. Thermal efficiency influenced by several factors such 
as instant solar radiation, ambient temperature, inlet temperature and outlet fluid temperature. Sensitively study is required to investigate the effect of back surface temperature on thermal efficiency. Electrical efficiency was in the range of $14.7 \%$ at 9 $\mathrm{AM}$ to $15.5 \%$ at $4 \mathrm{PM}$. The minimum efficiency was $14.3 \%$ between $11 \mathrm{AM}$ and $12 \mathrm{PM}$ due to the increase in the PV cell temperature. Electrical efficiency decreased by $2.72 \%$ due to the increase in PV cell temperature by $19.4 \%$ from the morning until $11 \mathrm{PM}$ and increased by $7.6 \%$ due to the decrease in PV cell temperature by $48.32 \%$ from $12 \mathrm{PM}$ until 4 PM. Figure 5 shows thermal and electrical efficiency during the day.

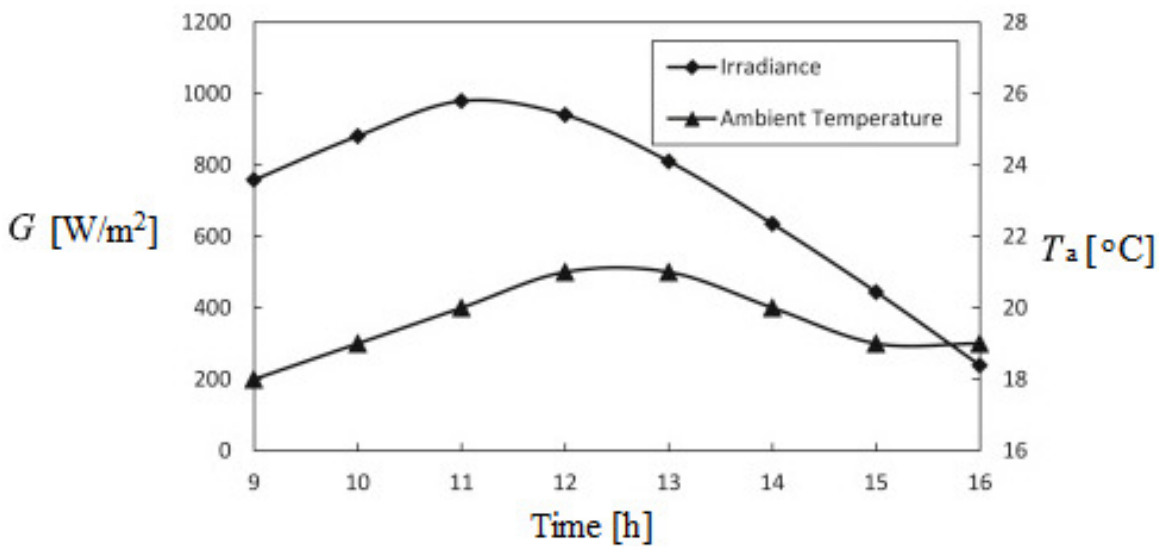

Figure 3. Variation of the solar radiation and ambient temperature throughout the test day [12]

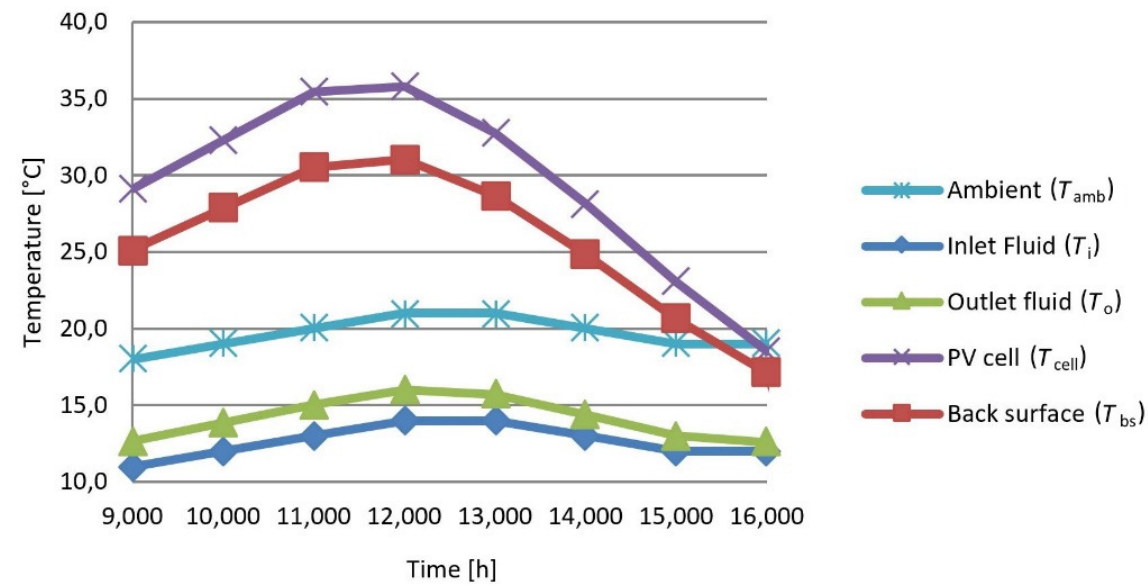

Figure 4. Variation of different temperatures that affected the PVT module during the day

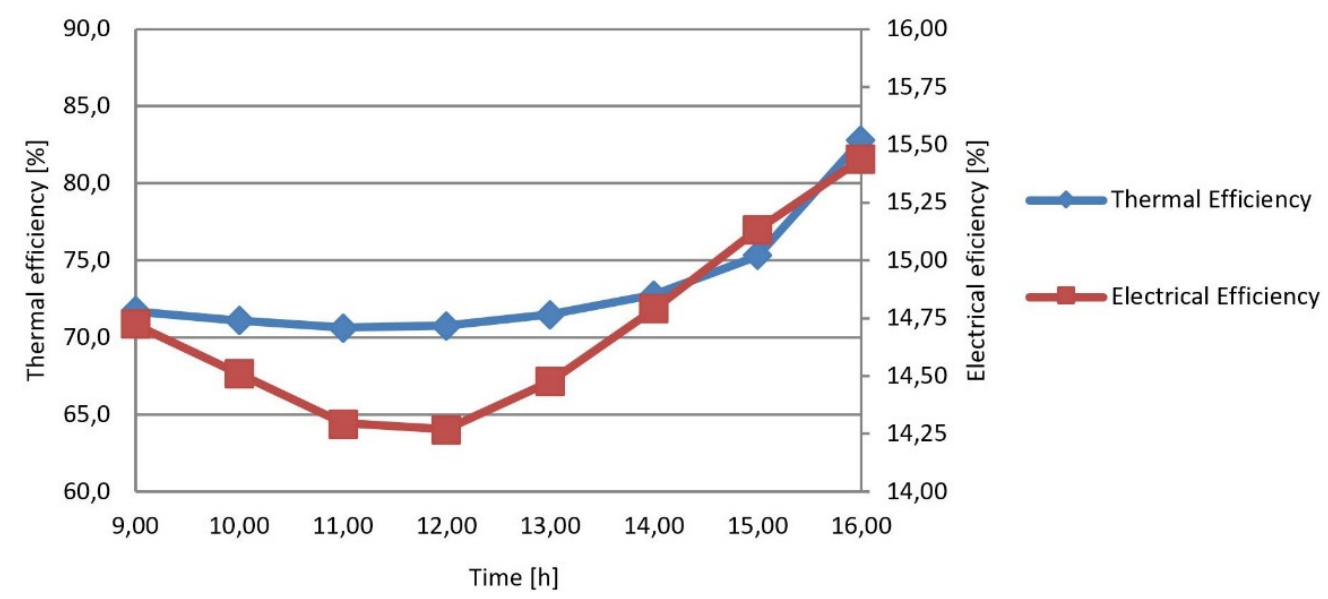

Figure 5. Thermal and electrical efficiency of the PVT module during the day 


\section{Mathematical model validation}

The temperature difference between the PV cell temperatures in the mathematical model of the PVT and the experiment was in the range of $0.3{ }^{\circ} \mathrm{C}$ to $6.5^{\circ} \mathrm{C}$. However, the trends are in agreement as shown in Figure 6.

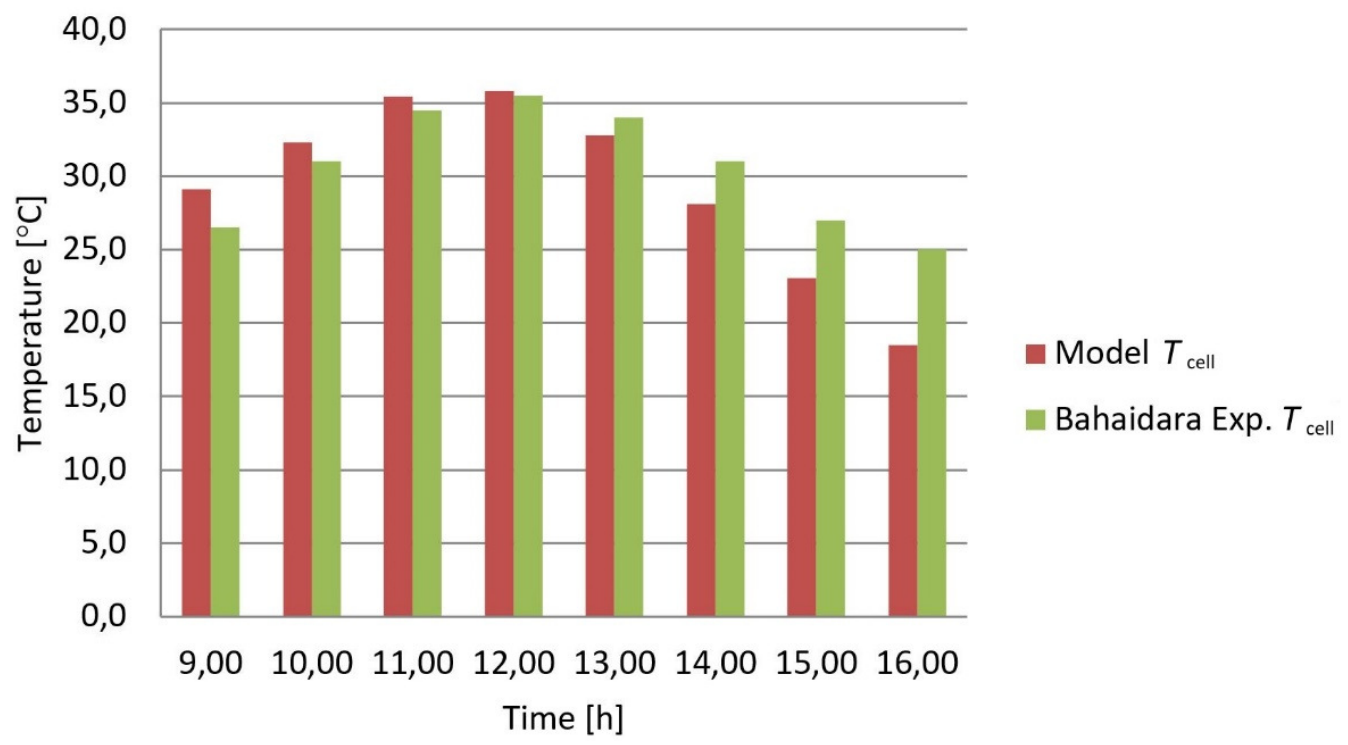

Figure 6. Calculated PV cell temperature ( $\left.T_{\text {cell }}\right)$ vs. Bahaidara experimental data [21] (Saudi Arabia-Dhahran)

Back surface temperature was also calculated by the mathematical model throughout the day then validated against the experiment. Figure 7 shows the agreement between back surface temperature $\left(T_{\mathrm{bs}}\right)$ for the PVT model and the experiment. Both of experimental and calculated values had the same trend which increased during the day due to the increase in solar radiation and ambient temperature until reaching the maximum temperature at $12 \mathrm{PM}$ before decreasing until the end of the day. The temperature difference between the back surface temperatures in the mathematical model of the PVT and the experiment was in the range of $0.8^{\circ} \mathrm{C}$ to $5.5^{\circ} \mathrm{C}$.

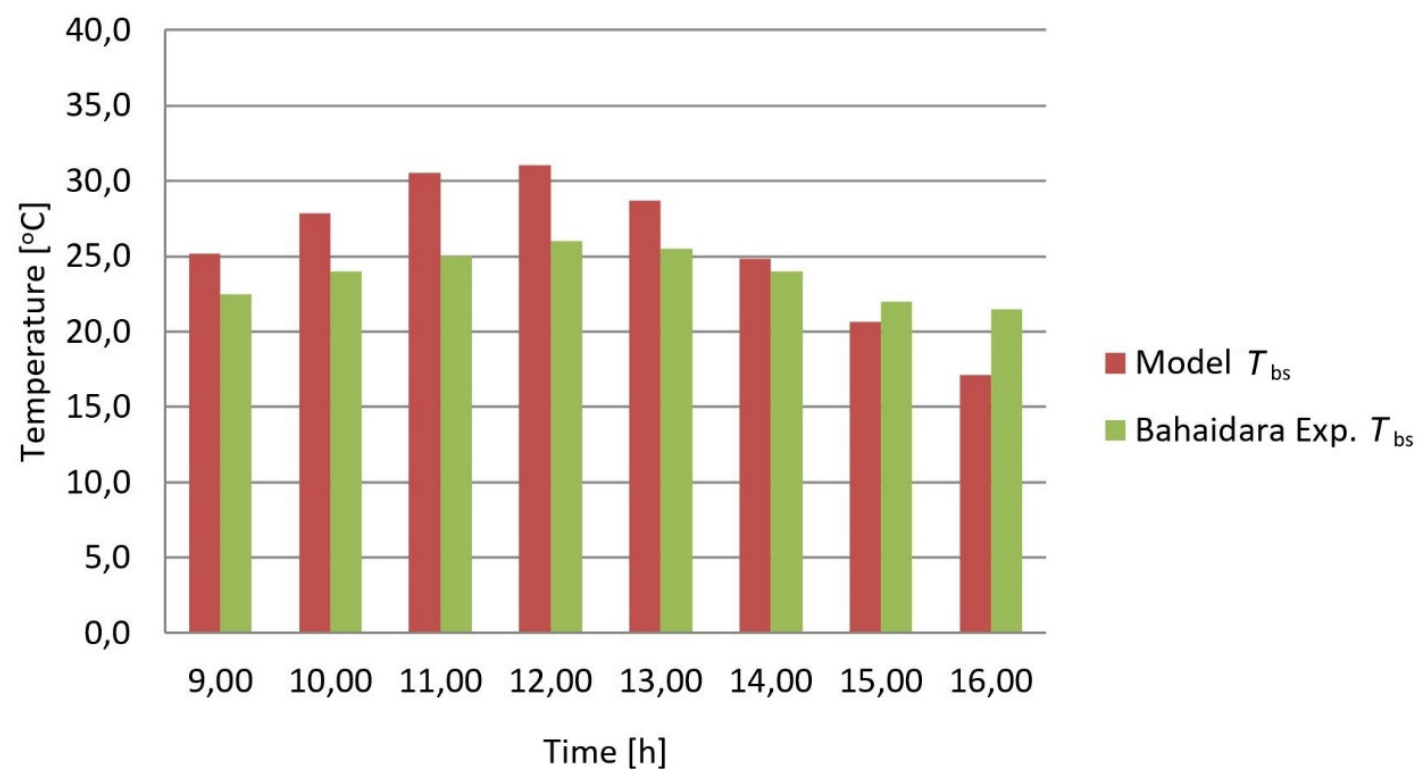

Figure 7. Calculated back surface temperature $\left(T_{\mathrm{bs}}\right)$ vs. Bahaidara experimental data [21] (Saudi Arabia-Dhahran) 
The maximum electrical power during the day was $174 \mathrm{~W}$ by the PVT model at $11 \mathrm{PM}$ due to the solar radiation and ambient temperature values while was measured of $210 \mathrm{~W}$ at the same time from the experiment. Figure 8 shows the comparison between calculated electrical power by the PVT model and the data from the experiment. Electric power difference between the mathematical model of the PVT and the experiment was in the range of $4 \mathrm{~W}$ to $36 \mathrm{~W}$.

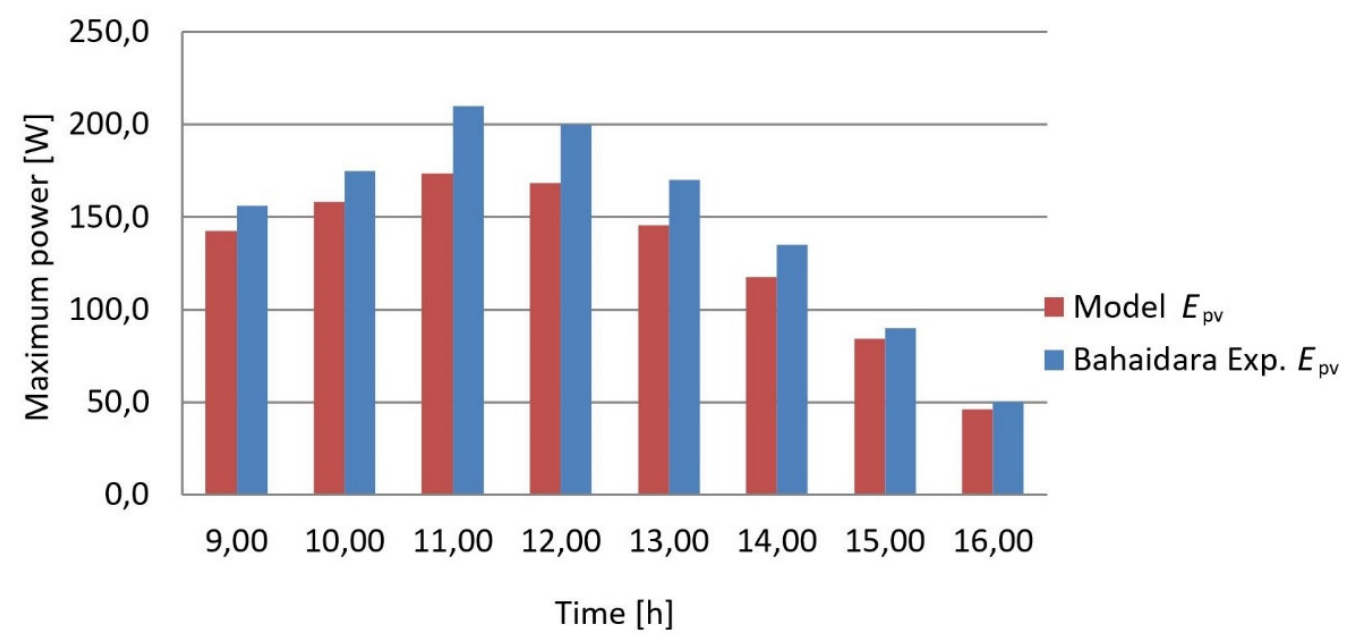

Figure 8. Calculated maximum electric power vs. experimental data (Saudi Arabia-Dhahran)

\section{Cooling piping configuration for the Photovoltaic Thermal}

In the previous section, the PVT module is cooled as one area $\left(A=1.24 \mathrm{~m}^{2}\right)$ and the performance of the PVT at 12 PM were: $T_{\mathrm{i}}=14{ }^{\circ} \mathrm{C}, T_{\mathrm{a}}=21{ }^{\circ} \mathrm{C}, G=950 \mathrm{~W} / \mathrm{m}^{2}$, $Q_{\mathrm{u}}=834 \mathrm{~J} / \mathrm{s}, T_{\mathrm{o}}=16{ }^{\circ} \mathrm{C}$, thermal efficiency $=70.8 \%, T_{\text {cell }}=35.8^{\circ} \mathrm{C}$, electrical efficiency $=14.3 \%$ and electrical power $=168 \mathrm{~W}$.

In this section, the PVT is divided into 72 cells $\left(A_{\text {cell }}=0.01722 \mathrm{~m}^{2}\right)$ which represent the total area and the piping was designed to connect cells in series. Configuration of the PVT is shown in Figure 9.

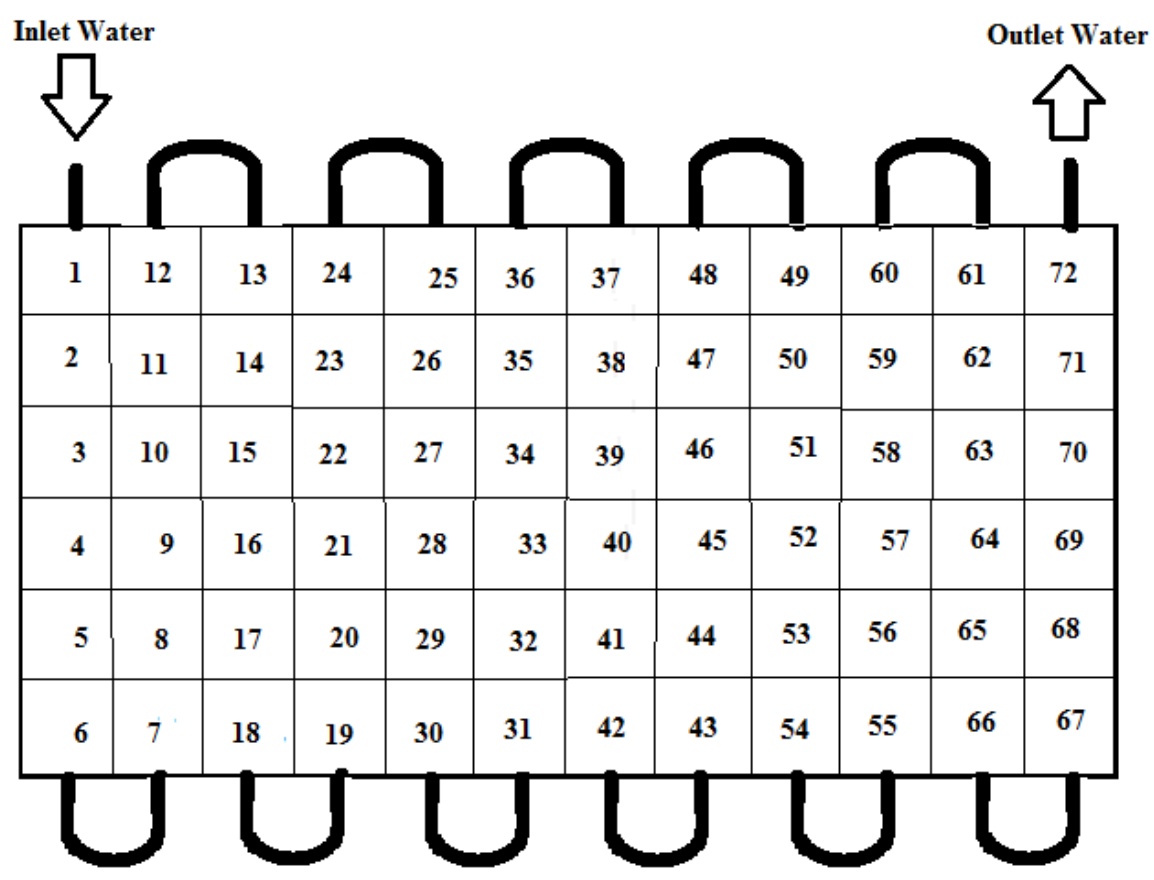

Figure 9. Arrangement of PVT for cells linked thermally in series 
Eqs $(3,12,15)$ were applied to each cell individually in order to carry out cells temperatures and efficiencies. Based on weather data that are illustrated in Figure 3 and Figure 4, the performances of the PVT module at $12 \mathrm{PM}$ for $14{ }^{\circ} \mathrm{C}$ inlet water temperature were determined by considering the 72 cells in series as in Figures 10,11 and 12. Figure 10 shows individual PV cells temperature for the panel from the inlet at the first cell until cell number 72 where the water leaves the collector. Cell temperatures were increased from inlet to the outlet due to the increase in water temperature.

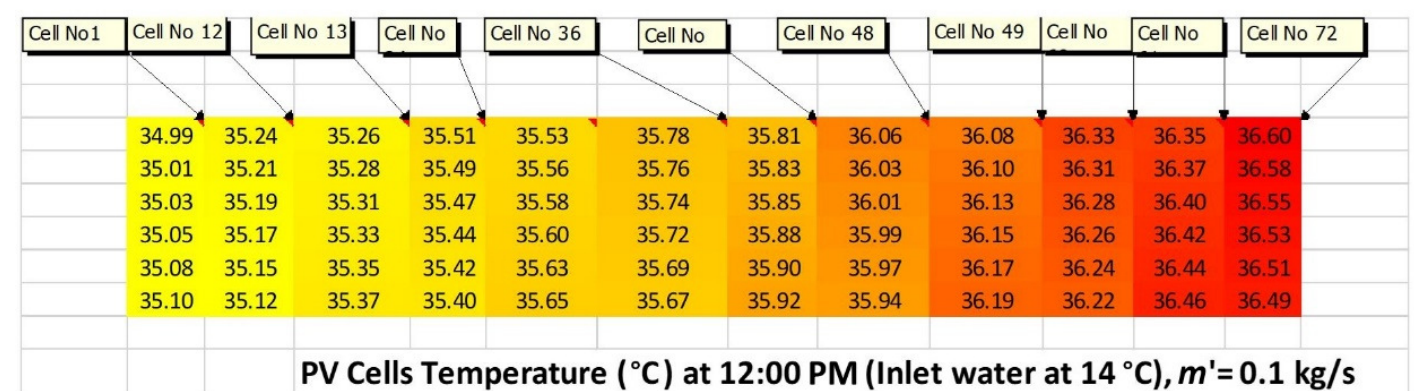

Figure 10. PVT cell temperature at 12:00 PM and inlet water at $14{ }^{\circ} \mathrm{C}$

PVT electrical efficiency was decreased from $14.33 \%$ at the inlet cell to $14.22 \%$ at the outlet cell due to the increase in the PV cell temperature. Figure 9 shows electrical efficiency for each cell in the panel at 12:00 PM.

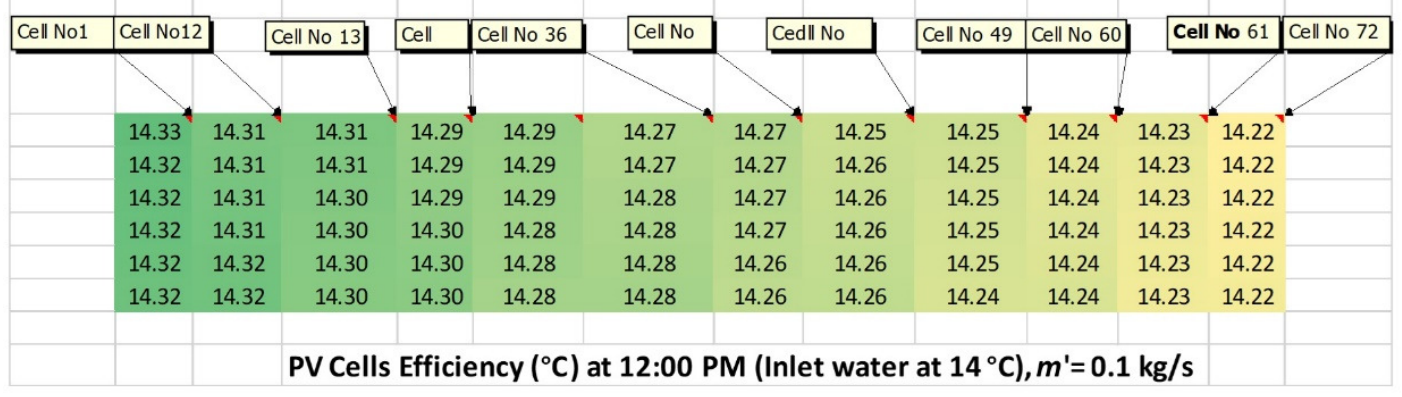

Figure 11. PVT electric efficiency at 12:00 PM and inlet water at $14{ }^{\circ} \mathrm{C}$

PVT thermal efficiency was decreased from $70.79 \%$ at the inlet cell to $69.66 \%$ at the outlet cell due to the increase in water temperature through the cells. Figure 10 shows thermal efficiency for each cell in the panel at 12:00 PM.

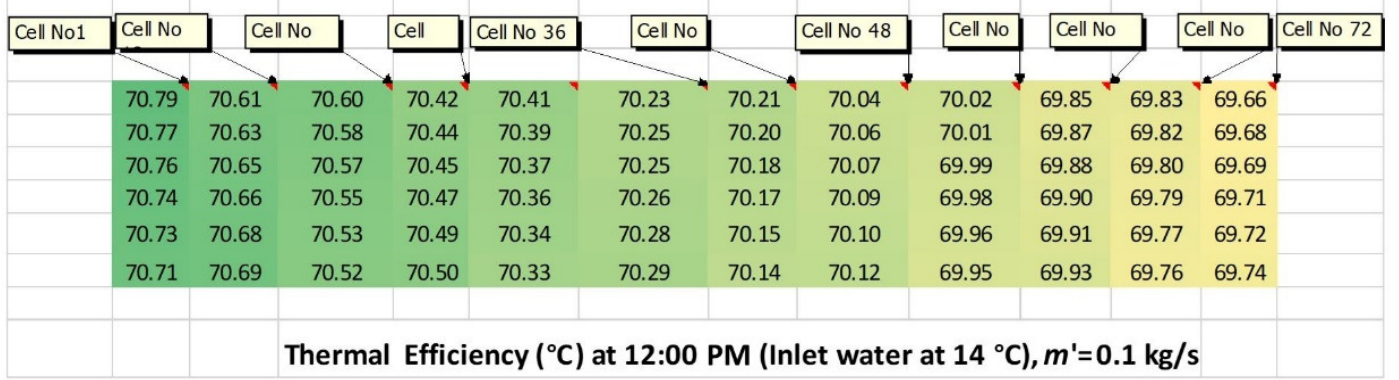

Figure 12. PVT thermal efficiency at 12:00 PM and inlet water at $14{ }^{\circ} \mathrm{C}$

The benefit of connecting cells in series needs to be investigated in the future, this can help to increase the outlet water temperature and to determine the optimum location for 
PV cells when the partial PV surface is applied. The outlet water temperature is a key parameter that affects the overall performance of solar cooling systems such as absorption system.

\section{Photovoltaic Thermal performance for different inlet temperature and different numbers of panels in series}

The performance of PVT was calculated based on the heat transfer equations that were discussed in the previous sections. To meet the requirement for solar cooling systems, the best options based on PVT outlet temperature need to be selected and PVT water flow rate need to be optimized in order reach the highest energy saving. The average PV cell temperature should not exceed the maximum operation temperature in the manufacturing specifications of the photovoltaic cells.

The following performance figures are based on 72 panels connected in an array. Each panel has an area of $1.72 \mathrm{~m}^{2}$ and water flowrate of $0.1 \mathrm{~kg} / \mathrm{s}$. There are many options for the number of panels that should be linked in series in order to achieve specified outlet temperature. Figure 13 shows the arrangements for a PVT system that could be made of 72 panels. The arrangements could include: one line of 72 panels connected in series $(L=1$ and $N=72$ ), 2 lines of 36 panels in series, 3 lines of 24 panels in series, 4 lines of 18 panels in series, 6 lines of 12 panels in series, 8 lines of 9 panels in series, 9 lines of 8 panels in series, 12 lines of 6 panels in series, 18 lines of 4 panels in series, 36 lines of 2 panels in series or 72 panel connected in parallel to the inlet and outlet header $(L=72$ and $N=1)$.

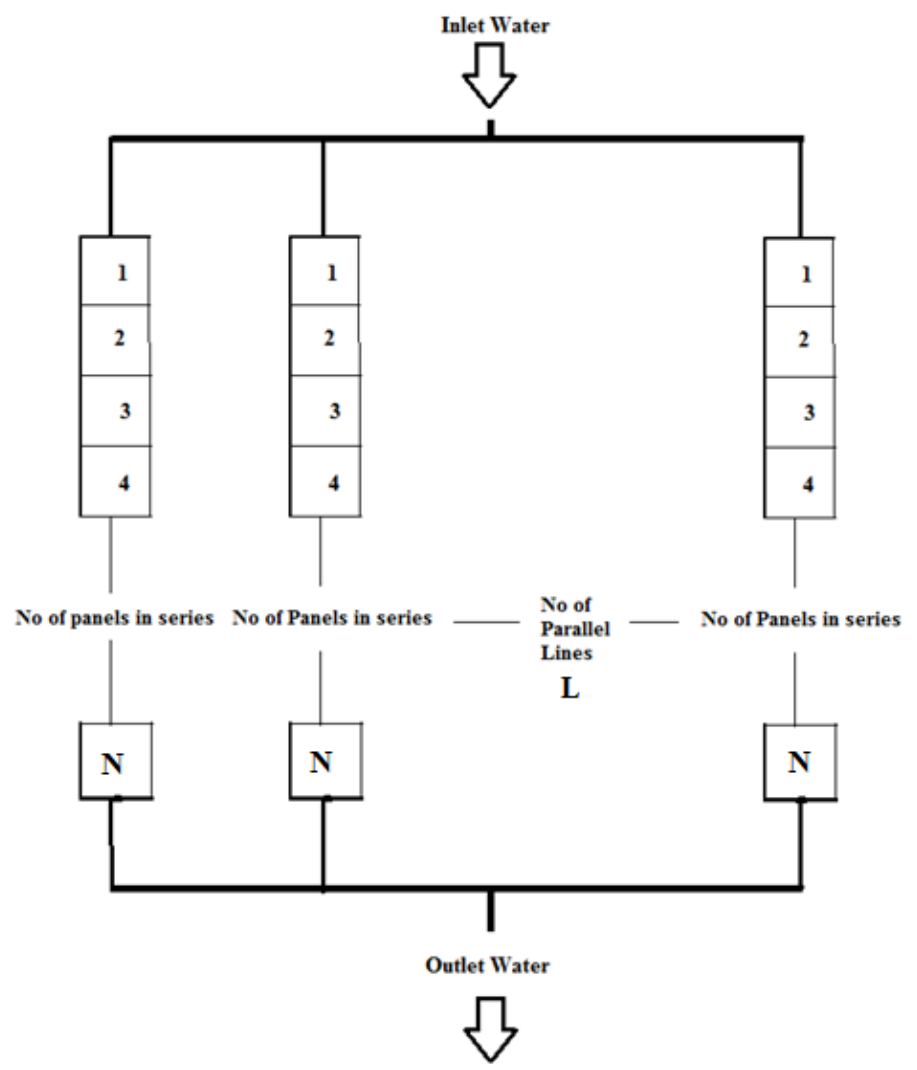

Figure 13. The proposed arrangement for a PVT system, which based on 72 panels connected in an array

Figures 14 to 17 illustrate the performance of PVT module starting from cooling each panel individually $(N=1)$ then two panels in series $(N=2)$ until 72 panel in series $(N=72)$. The number $4(N=4)$ in the $\mathrm{x}$-axis means that the configuration consist of 18 
lines $(L=18)$ in parallel, each lines consist of 4 panels connected in series and the outlet for each lines supply the main header.

For the same numbers of panels, the configuration of connecting them affected the outlet water temperature which was in the range of $25^{\circ} \mathrm{C}$ to $110^{\circ} \mathrm{C}$. The more panels connected in series, the higher the outlet temperature is achieved. Figure 14 shows outlet water temperature for different inlet temperature, which have the same trend and the high inlet temperature, the high outlet temperature is reached.

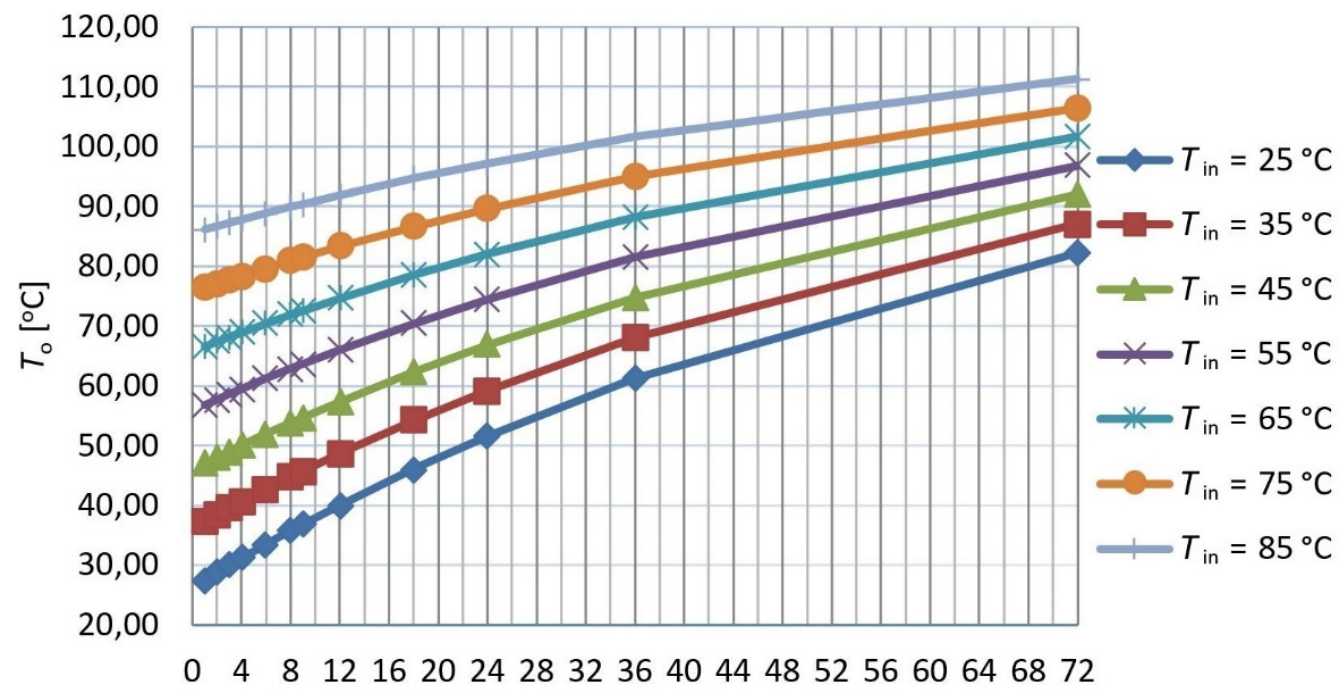

No. of panels in series

Figure 14. PVT outlet fluid temperature for different inlet temperature

Figure 15 shows average thermal efficiency for different inlet temperature, which was in the range of $15 \%$ to $65 \%$. For all cases, the low inlet temperature, the more thermal efficiency was achieved.

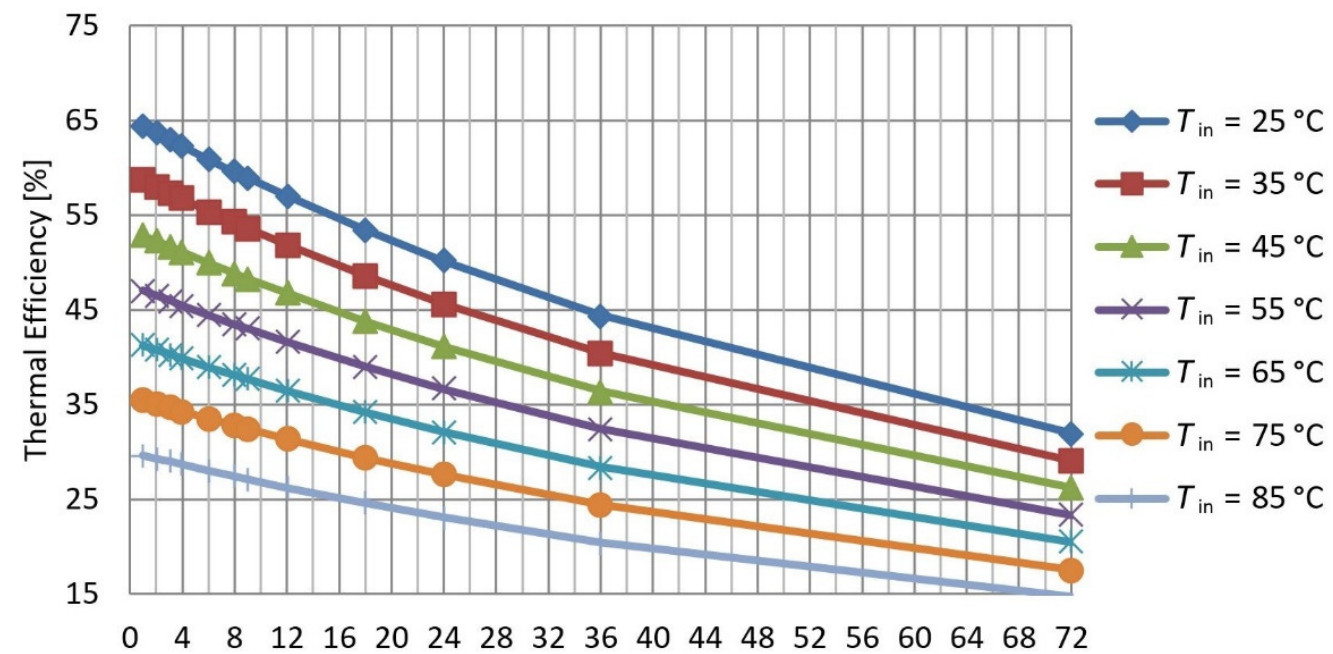

No. of panels in series

Figure 15. PVT thermal efficiency for different inlet temperature

Average electrical efficiency, which was in the range of $8.9 \%$ to $13.7 \%$, was also influenced by the configuration of the PVT. The lower inlet temperature, the higher electric efficiency was achieved as in Figure 16. 


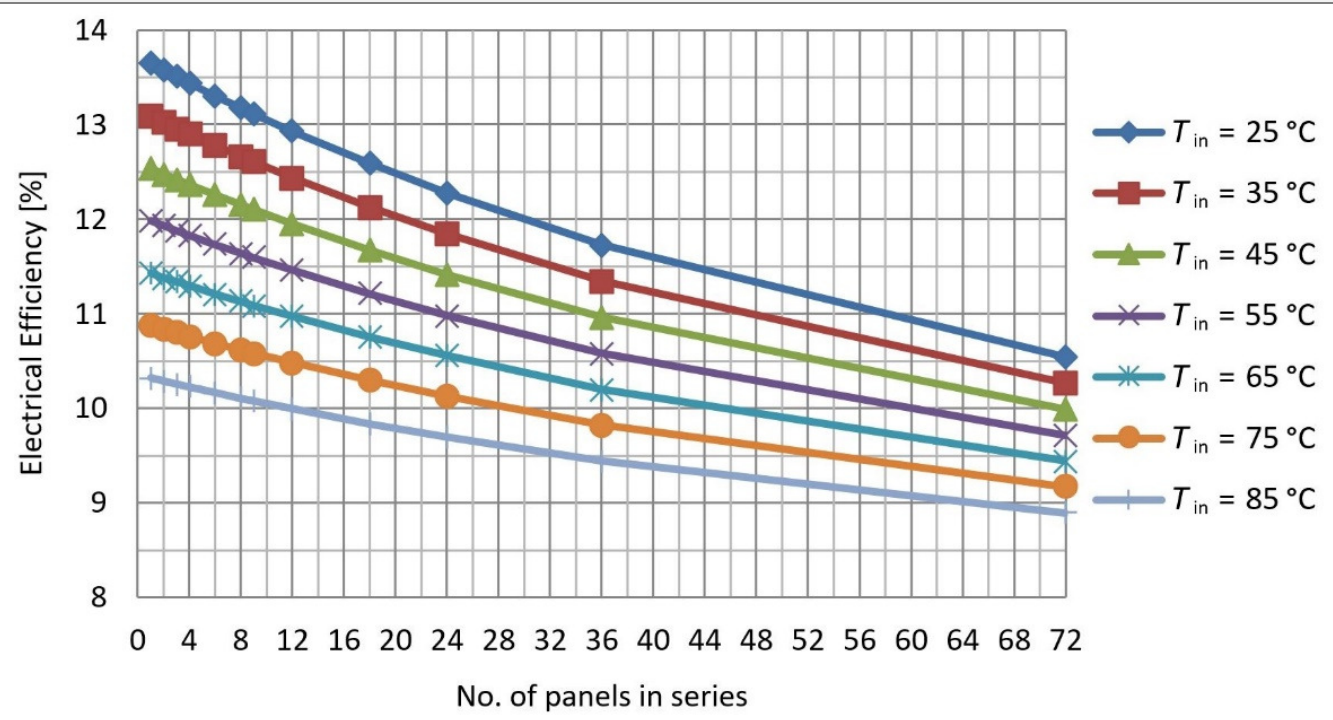

Figure 16. PVT electrical efficiency for different inlet temperature

Figure 17 shows the average photovoltaic cell temperature, which was in the range of $45{ }^{\circ} \mathrm{C}$ to $115{ }^{\circ} \mathrm{C}$ for all cases. Cell temperature is an important factor to select the configuration, which should not exceed the manufacturing specification for the maximum temperature.

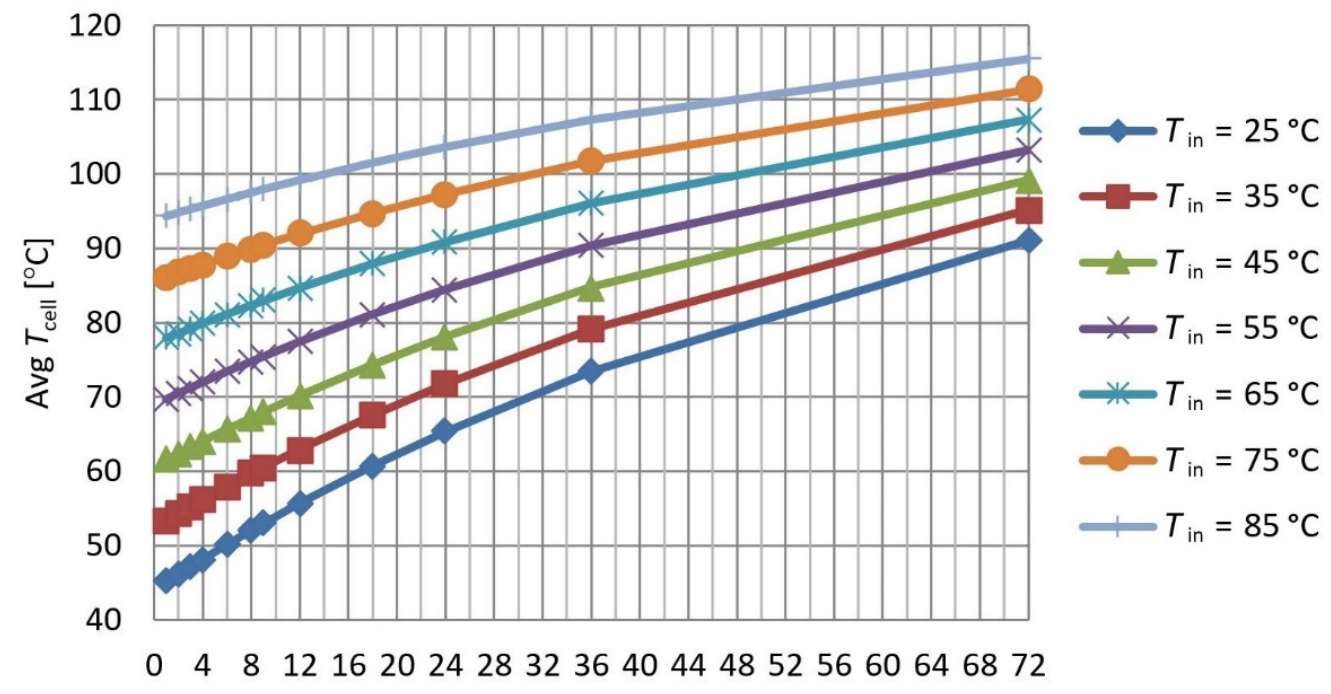

No. of panels in series

Figure 17. PVT average cells temperature for different inlet temperature

\section{ACKNOWLEDGMENT}

This research was made possible by Majmaa University grant from Saudi Arabia government fund. The statements made are solely the responsibility of the authors.

\section{CONCLUSIONS}

This research describes the design and analysis of a PVT system for producing electricity and thermal energy. The performance of the PVT system is based on several factors that includes PVT's materials, design, ambient temperature, inlet and outlet fluid temperature and PV cell temperature. The overall PVT system performance is calculated by using mathematical method. 
The results which were based on the climate conditions, show that the PVT performance were influenced by several factors that included instant solar radiation, ambient temperature, inlet fluid temperature, PV cell temperature and back surface temperature. Electrical efficiency was in the range of $14.7 \%$ to $15.5 \%$ and sensitive to the PV cell temperature. It decreased from $14.72 \%$ to $14.27 \%$ due to the increase in PV cell temperature from $29.1{ }^{\circ} \mathrm{C}$ to $35.8{ }^{\circ} \mathrm{C}$ and increased to $15.44 \%$ due to the decrease in PV cell temperature to $18.5^{\circ} \mathrm{C}$. Thermal efficiency was in the range of $72 \%$ to $83 \%$ and was influenced by several factors such as instant solar radiation, ambient temperature, inlet temperature and outlet fluid temperature. Sensitively study is required to investigate the effect of back surface temperature on thermal efficiency.

A PVT arrangement was proposed which connects cells thermally in series in the same panel. Cell temperatures increased from inlet to the outlet due to the increase in water temperature. PVT electrical efficiency decreased from $14.33 \%$ at the inlet cell to $14.22 \%$ at the outlet cell due to the increase in the PV cell temperature. PVT thermal efficiency decreased from $70.79 \%$ at the inlet cell to $69.74 \%$ at the outlet cell due to the increase in water temperature through the cells.

Another arrangement was proposed for a PVT system, which based on 72 panels connected in one array. PVT performance curves were worked out for different inlet water temperature. Different configurations of connecting panels in series were also investigated. The more panels connected in series, the higher the outlet temperature. Average thermal efficiency for different inlet temperature was in the range of $15 \%$ to $65 \%$. For all cases, the lower the inlet temperature, the more thermal efficiency was achieved. Average electrical efficiency, which was in the range of $8.9 \%$ to $13.7 \%$, was also influenced by the configuration of the PVT. The lower the inlet temperature, the higher electric efficiency was achieved. Average photovoltaic cell temperature was in the range of $45^{\circ} \mathrm{C}$ to $115^{\circ} \mathrm{C}$ for all cases. Cell temperature is an important factor to select the configuration, which should not exceed the manufacturing specification for the maximum temperature.

Further research is required to determine the optimum location for PV cell when the partial PV surface is applied. The outlet water temperature, which is a key parameter that affects the overall performance of solar cooling system, needs to be optimized.

\section{NOMENCLATURE}

$A_{\mathrm{c}}$

$C_{\mathrm{p}}$

$F$

$F^{\prime}$

$F_{\mathrm{R}}$

G

$h$

$h_{\mathrm{f}}$

$h_{\mathrm{o}}$

$h_{\mathrm{p} 1}$

$h_{\mathrm{p} 2}$

$h_{\mathrm{T}}$

$I_{(\mathrm{t})}$

$I_{\mathrm{mpp}}$

$I_{\mathrm{p}}$

$I_{\mathrm{s}}$

$L_{\mathrm{g}}$

$L_{\mathrm{si}}$ collector area

specific heat of the coolant

fin efficiency factor

flat plate collector efficiency factor

heat removal factor

incidence solar irradiance normal to the surface

heat transfer coefficient

heat transfer coefficient to fluid

heat transfer coefficient to ambient

penalty factor due to the glass cover of PV module

penalty factor due to the absorber below PV module

heat transfer coefficient back surface of tedlar to fluid

incident solar intensity

electric current at maximum power point

solar radiation perpendicular to collector surface

solar radiation reaching the solar collector

the thickness of glass cover

the thickness of silicon solar cell $\left[\mathrm{m}^{2}\right]$

$[\mathrm{kJ} / \mathrm{kgK}]$

$[-]$

$[-]$

$[-]$

$\left[\mathrm{W} / \mathrm{m}^{2}\right]$

$\left[\mathrm{W} / \mathrm{m}^{2}\right]$

$\left[\mathrm{W} / \mathrm{m}^{2}\right]$

$\left[\mathrm{W} / \mathrm{m}^{2}\right]$

[-]

[-]

$\left[\mathrm{W} / \mathrm{m}^{2} \mathrm{~K}\right]$

$\left[\mathrm{W} / \mathrm{m}^{2}\right]$

[A]

$\left[\mathrm{W} / \mathrm{m}^{2}\right]$

$\left[\mathrm{W} / \mathrm{m}^{2}\right]$

[m]

[m] 


\begin{tabular}{|c|c|c|}
\hline$m^{\prime}$ & mass flowrate of the coolant & {$[\mathrm{kg} / \mathrm{s}]$} \\
\hline$Q$ & heat transfer rate & {$[\mathrm{kW}]$} \\
\hline$Q_{\mathrm{u}}$ & useful energy output from the solar collector & {$[\mathrm{kW}]$} \\
\hline$T_{\mathrm{a}}$ & ambient temperature & {$\left[{ }^{\circ} \mathrm{C}\right]$} \\
\hline$T_{\mathrm{f}}$ & fluid temperature & {$\left[{ }^{\circ} \mathrm{C}\right]$} \\
\hline$T_{\text {in }}$ & inlet temperature of the coolant & {$\left[{ }^{\circ} \mathrm{C}\right]$} \\
\hline$T_{\text {out }}$ & outlet temperature of the coolant & {$\left[{ }^{\circ} \mathrm{C}\right]$} \\
\hline$T_{\mathrm{pm}}$ & mean temperature for the absorber plate collector & {$\left[{ }^{\circ} \mathrm{C}\right]$} \\
\hline$U_{\mathrm{b}}$ & $\begin{array}{l}\text { an overall back loss coefficient from flowing water } \\
\text { to ambient }\end{array}$ & {$\left[\mathrm{W} / \mathrm{m}^{2} \mathrm{~K}\right.$} \\
\hline$U_{\mathrm{L}}$ & $\begin{array}{l}\text { an overall heat loss coefficient from the } \mathrm{PV} / \mathrm{T} \text { water } \\
\text { collector to the environment }\end{array}$ & {$\left[\mathrm{W} / \mathrm{m}^{2} \mathrm{~K}\right.$} \\
\hline$U_{\mathrm{t}}$ & $\begin{array}{l}\text { an overall heat transfer coefficient from solar cell to } \\
\text { ambient through glass cover }\end{array}$ & {$\left[\mathrm{W} / \mathrm{m}^{2} \mathrm{~K}\right.$} \\
\hline$U_{\mathrm{T}}$ & $\begin{array}{l}\text { an overall heat transfer coefficient from solar cell to } \\
\text { flowing water through tedlar }\end{array}$ & {$\left[\mathrm{W} / \mathrm{m}^{2} \mathrm{~K}\right.$} \\
\hline$U_{\mathrm{tf}}$ & $\begin{array}{l}\text { an overall heat transfer coefficient from glass to water } \\
\text { through solar cell and tedlar }\end{array}$ & {$\left[\mathrm{W} / \mathrm{m}^{2} \mathrm{~K}\right.$} \\
\hline$U_{\mathrm{tT}}$ & $\begin{array}{l}\text { an overall heat transfer coefficient from glass to tedlar } \\
\text { through solar cell }\end{array}$ & {$\left[\mathrm{W} / \mathrm{m}^{2} \mathrm{~K}\right.$} \\
\hline$V_{\mathrm{mpp}}$ & electric voltage at maximum power point & {$[\mathrm{V}]$} \\
\hline
\end{tabular}

\section{Greek letters}

$\begin{array}{ll}\alpha & \text { absorbance } \\ \beta_{\mathrm{c}} & \text { packing factor of solar cell } \\ \beta_{\mathrm{o}} & \text { photovoltaic temperature coefficient } \\ \eta & \text { efficiency } \\ \eta_{\mathrm{elc}} & \text { photovoltaic electrical efficiency } \\ \eta_{\mathrm{o}} & \text { reference cell efficiency } \\ \eta_{\mathrm{th}} & \text { photovoltaic thermal efficiency } \\ \eta_{\mathrm{tot}} & \text { photovoltaic overall efficiency } \\ \tau & \text { transmittance } \\ \epsilon & \text { emittance }\end{array}$

\section{Abbreviations}

$\begin{array}{ll}\text { COP } & \text { Coefficient of Performance } \\ \text { PV } & \text { Photovoltaic Panel } \\ \text { SF } & \text { Solar Fraction }\end{array}$

\section{REFERENCES}

1. Fumo, N., Bortone, V. and Zambrano, J., Comparative Analysis of Solar Thermal Cooling and Solar Photovoltaic Cooling Systems, Journal of Solar Energy Engineering, Vol. 135, No. 2, p 021002, 2013, https://doi.org/10.1115/1.4007935

2. Eicker, U., Colmenar-Santos, A., Teran, L., Cotrado, M. and Borge-Diez, D., Economic evaluation of Solar Thermal and Photovoltaic Cooling Systems through Simulation in different Climatic Conditions: An analysis in three different Cities in Europe, Energy and Buildings, Vol. 70, pp 207-223, 2014, https://doi.org/10.1016/j.enbuild.2013.11.061

3. Prasartkaew, B., Mathematical modeling of an Absorption Chiller System energized by a Hybrid Thermal System: Model Validation, Energy Procedia, Vol. 34, pp 159-172, 2013, https://doi.org/10.1016/j.egypro.2013.06.744 
4. Pazheri, F. R., Malik, N. H., Al-Arainy, A. A. and Ahamed, I., Use of Renewable Energy Sources in Saudi Arabia through Smart Grid, Journal of Energy and Power Engineering, Vol. 6, No. 7, pp 1065-1070, 2012.

5. Šúri, M., Huld, T. A., Dunlop, E. D. and Ossenbrink, H. A., Potential of Solar Electricity Generation in the European Union Member States and Candidate Countries, Solar Energy, Vol. 81, No. 10, pp 1295-1305, 2007, https://doi.org/10.1016/j.solener.2006.12.007

6. Hepbasli, A. and Alsuhaibani, Z., A Key Review on Present Status and Future Directions of Solar Energy Studies and Applications in Saudi Arabia, Renewable and Sustainable Energy Reviews, Vol. 15, No. 9, pp 5021-5050, 2011, https://doi.org/10.1016/j.rser.2011.07.052

7. Pampuri, L., Cereghetti, N., Strepparava, D. and Caputo, P., Analysis of the Electricity Consumptions: A first Step to develop a District Cooling System, Sustainable Cities and Society, Vol. 23, pp 23-36, 2016, https://doi.org/10.1016/j.scs.2016.02.015

8. Sadiq Munfath Khan, M. and Orfi, J., Cooling Performance and Energy saving analysis of Cascade Refrigeration System powered by Solar Energy for Riyadh Region (Saudi Arabia), International Journal of Sustainable Building Technology and Urban Development, Vol. 5, No. 1, pp 44-52, 2014, https://doi.org/10.1080/2093761X.2013.875492

9. Fang, G., Hu, H. and Liu, X., Experimental investigation on the Photovoltaic-thermal Solar Heat Pump Air-conditioning System on Water-heating Mode, Experimental Thermal and Fluid Science, Vol. 34, No. 6, pp 736-743, 2010, https://doi.org/10.1016/j.expthermflusci.2010.01.002

10. Shirazi, A., Taylor, R. A., White, S. D. and Morrison, G. L., A Systematic Parametric Study and feasibility assessment of Solar-assisted Single-effect, Double-effect, and Triple-effect Absorption Chillers for Heating and Cooling Applications, Energy Conversion and Management, Vol. 114, pp 258-277, 2016, https://doi.org/10.1016/j.enconman.2016.01.070

11. Alobaid, M., Hughes, B., Kaiser Calautit, J., O'Connor, D. and Heyes, A., A Review of Solar driven Absorption Cooling with Photovoltaic Thermal Systems, Renewable and Sustainable Energy Reviews, Vol. 76, pp 728-742, 2017, https://doi.org/10.1016/j.rser.2017.03.081

12. Bahaidarah, H., Subhan, A., Gandhidasan, P. and Rehman, S., Performance evaluation of a PV (photovoltaic) Module by Back Surface Water Cooling for Hot Climatic Conditions, Energy, Vol. 59, pp 445-453, 2013, https://doi.org/10.1016/j.energy.2013.07.050

13. Mittelman, G., Kribus, A. and Dayan, A., Solar cooling with concentrating Photovoltaic/thermal (CPVT) Systems, Energy Conversion and Management, Vol. 48, No. 9, pp 2481-2490, 2007, https://doi.org/10.1016/j.enconman.2007.04.004

14. Vokas, G., Christandonis, N. and Skittides, F., Hybrid Photovoltaic-thermal Systems for Domestic heating and cooling - a Theoretical approach, Solar Energy, Vol. 80, No. 5, pp 607-615, 2006, https://doi.org/10.1016/j.solener.2005.03.011

15. Calise, F., d'Accadia, M. D. and Vanoli, L., Design and Dynamic Simulation of a Novel Solar Trigeneration System based on Hybrid Photovoltaic/thermal Collectors (PVT), Energy Conversion and Management, Vol. 60, pp 214-225, 2012, https://doi.org/10.1016/j.enconman.2012.01.025

16. Calise, F., Dentice d'Accadia, M., Palombo, A. and Vanoli, L., Dynamic Simulation of a Novel High-temperature Solar Trigeneration System based on concentrating Photovoltaic/thermal Collectors, Energy, Vol. 61, pp 72-86, 2013, https://doi.org/10.1016/j.energy.2012.10.008

17. Aste, N., del Pero, C. and Leonforte, F., Water Flat Plate PV - Thermal Collectors: A Review, Solar Energy, Vol. 102, pp 98-115, 2014, https://doi.org/10.1016/j.solener.2014.01.025 
18. Cristofari, C., Notton, G. and Canaletti, J. L., Thermal behavior of a Copolymer PV/Th Solar System in Low Flow Rate Conditions, Solar Energy, Vol. 83, No. 8, pp 1123-1138, 2009, https://doi.org/10.1016/j.solener.2009.01.008

19. Dubey, S. and Tay, A. A., The Theoretical modelling and optimization of a $10 \mathrm{KW}_{\mathrm{P}}$ Photovoltaic Thermal System for a Student Hostel in Singapore, International Journal of Green Energy, Vol. 11, No. 3, pp 225-239, 2014, https://doi.org/10.1080/15435075.2013.769880

20. Yazdanifard, F., Ebrahimnia-Bajestan, E. and Ameri, M., Investigating the Performance of a Water-based Photovoltaic/thermal (PV/T) Collector in Laminar and Turbulent Flow Regime, Renewable Energy, Vol. 99, pp 295-306, 2016, https://doi.org/10.1016/j.renene.2016.07.004

21. Bahaidarah, H. M., Rehman, S., Gandhidasan, P. and Tanweer, B., Experimental evaluation of the Performance of a Photovoltaic Panel with Water Cooling, Photovoltaic Specialists Conference (PVSC), 2013 IEEE 39 ${ }^{\text {th }}$, IEEE, 2013, https://doi.org/10.1109/PVSC.2013.6745090

22. Duffie, J. A. and Beckman, W. A., Solar Engineering of Thermal Processes, Vol. 3, Wiley: New York, New York, USA, 1980.

23. Touafek, K., Khelifa, A. and Adouane, M., Theoretical and Experimental Study of Sheet and Tubes Hybrid PVT Collector, Energy Conversion and Management, Vol. 80, pp 71-77, 2014, https://doi.org/10.1016/j.enconman.2014.01.021

24. Chow, T. T., A Review on Photovoltaic/thermal Hybrid Solar Technology, Applied Energy, Vol. 87, No. 2, pp 365-379, 2010 , https://doi.org/10.1016/j.apenergy.2009.06.037

25. Al-Ajlan, S., Al Faris, H. and Khonkar, H., A Simulation modeling for optimization of Flat Plate Collector design in Riyadh, Saudi Arabia, Renewable Energy, Vol. 28, No. 9, pp 1325-1339, 2003, https://doi.org/10.1016/S0960-1481(02)00254-9 